Jurnal Indonesia Sosial Teknologi: p-ISSN: 2723 - 6609

e-ISSN : 2548-1398

Vol. 1, No. 3 Oktober 2020

\title{
PENERAPAN KONSEP LEAN MANUFACTURING UNTUK RANCANGAN USULAN PERBAIKAN MINIMASI WASTE DEFECT DENGAN METODE POKA YOKE PADA PT. TETRA MITRA SINERGIS
}

\author{
Bintang Nusantara Adji, Zeny Fatimah Hunusalela dan Anggi Oktaviani \\ Universitas Indraprasta Pgri \\ Email : bintangnus.adji@gmail.com, zeny.fh86@gmail.com dan \\ Anggioktaviani.mt@gmail.com
}

\begin{abstract}
Abstrac
The main key of a company is to be able to survive and compete by focusing on quality, both product quality and the quality of the production process.products (Defective Defects) can be minimized as much as possible to reach products zero defect. This study aims to determine the quality of nickel chrome bolts, analyze the types of product defects and defects in the production process, priority product defects, the root causes of defects, and design a proposed repair at PT. Tetra Mitra Synergis. This study uses secondary data, namely production data and defect data on nickel chrome type K21 and K35 PT. Tetra Mitra Sinergis period July 2018 - June 2019. This study was analyzed using Pareto diagrams, fishbone diagrams, and brainstorming techniques. So from the results of the analysis it can be concluded that the defect percentage defects of bolts nickel chrome K35 and K21 at PT. Tetra Mitra Sinergis, the frequency of defects in the K21 844 bolt is 40\%, then the bolts type K35 Have a frequency of 1281 with a percentage of 60\%. Proposals for improvement that can be given using the Pokja Yoke method are to use several functions of Poké Yoke, namely giving an alarm when an error occurs in the form of immersion time in the acid solution bath and a control in the form of an operator who manually increases the zig manually. In addition, by adding operators on the Nickel line chrome to operate the engine and in case there is error line nickel chrome.
\end{abstract}

Keyword: Poka yoke, pareto and brainstorming

\begin{abstract}
Abstrak
Kunci utama sebuah perusahaan adalah dapat bertahan dan bersaing dengan berfokus kepada kualitas, baik kualitas produk maupun kualitas proses produksinya. Produk cacat (defect) dapat diminimalisir mungkin hingga mencapai produk zero defect. Penelitian ini bertujuan dapat mengetahui kualitas dari baut nickel chrome, menganalisis jenis kecacatan produk dan kecacatan pada proses produksinya, kecacatan produk prioritas, akar penyebab kecacatan, dan membuat rancangan usulan perbaikan di PT. Tetra Mitra Sinergis. Penelitian ini menggunakan data sekunder yaitu data produksi dan data cacat pada baut nickel chrome type K21 dan K35 PT. Tetra Mitra Sinergis periode juli 2018 - juni 2019. Penelitian ini dianalisis menggunakan diagram pareto, diagram tulang ikan (fishbone), dan teknik brainstorming. Maka dari hasil analisis dapat disimpulkan bahwa Cacat presentase cacat baut nikel chrome K35 dan K21 pada PT. Tetra Mitra Sinergis, frekuensi cacat pada baut K21 844 dengan persentase sebesar 40\%, selanjutnya baut type K35 memiliki frekuensi sebesar 1281 dengan persentase $60 \%$. Usulan perbaikan yang dapat diberikan dengan menggunakan metode poka yoke adalah dengan menggunakan beberapa fungsi poka yoke yaitu pemberian alarm pada saat terjadi kesalah berupa lamanya pencelupan
\end{abstract}


pada bak acid larutan dan control yang berupa operator yang dengan manual akan menaikan zig dengan manual. Selain itu dengan menambahkan operator pada line nickel chrome untuk mengoperasikan mesin dan berjaga-jaga jika ada kesalahan pada line nickel chrome.

Kata kunci: Poka yoke, pareto dan brainstorming

\section{Pendahuluan}

Perkembangan dunia industri di Indonesia yang semakin maju telah menimbulkan persaingan yang semakin ketat antar perusahaan dalam bidang industri, ringkas kata kemajuan teknologi saat ini benar-benar telah diakui dan dirasakan memberikan banyak kemudahan dan kenyamanan bagi kehidupan umat manusia (Dwiningrum \& Purbani, 2012). Maka untuk itu masyarakat indonesia perlu mempersiapkan diri agar tidak tertinggal oleh Negara-negara lainnya. Sebuah perusahaan harus bekerja keras agar terciptanya kualitas yang baik hal Hal ini disebabkan semakin pesatnya dunia industri dan banyak upaya inovatif untuk meningkatkan perusahaan yang bergerak dalam bidang manufaktur baik yang menyangkut sumber daya manusia dan mesin tersebut. (Wahyuningtias, 2013) Prinsip utama adalah pendekatan lean adalah pengurangan atau peniadaan pemborosan (waste). Dalam upaya menghilangkan waste, maka sangatlah penting untuk mengetahui apakah waste itu dan dimana ia berada. Ada 7 macam waste yang didefinisikan menurut (Hines \& Taylor, 2000)

PT. Tetra Mitra Sinergis merupakan perusahaan industri manufaktur yang bergerak dibidang elektroplating, perusahaan memporduksi plating dimana menghasilkan pelapisan logam mempunyai lapisan guna mencegah korosi dan meningkatkan daya estetika. Dengan berbagai permasalahan yang timbul pada perusahaan tersebut yang menyebabkan kualitas hasil plating pada jenis baut nickel chrome type K35 dan K21 pada line produksi nickel chrome periode juli 2018 - juni 2019 menurun karena adanya waste defect dimana pemborosan pada cacatnya/engie hasil plating sehingga terjadi pengeluaran biaya yang besar. Berikut adalah tabel I dan II adalah data produk cacat baut type K35.

Tabel I. Data produk cacat baut type K35

\begin{tabular}{cccccc}
\hline \multicolumn{5}{c}{ LAPORAN PRODUKSI FINISING PART PRODUK } \\
BAUT TYPE K35 BULAN JULI & 2018 - JUNI 2019 \\
\hline \multirow{3}{*}{ Bulan } & $\begin{array}{c}\text { Jumlah } \\
\text { produksi }\end{array}$ & $\begin{array}{c}\text { Cenis Cacat } \\
\text { Cacat }\end{array}$ & $\begin{array}{c}\text { Cacat } \\
\text { Wama }\end{array}$ & $\begin{array}{c}\text { Jumlah } \\
\text { Wacat }\end{array}$ & $\begin{array}{c}\text { Persentase } \\
\text { Cacat }\end{array}$ \\
\hline Juli & 2550 & 112 & 8 & 120 & $4,70 \%$ \\
Agt & 2000 & 42 & 7 & 49 & $2,50 \%$ \\
Sept & 2300 & 70 & 10 & 80 & $3,50 \%$ \\
Okt & 2600 & 118 & 9 & 127 & $4,90 \%$ \\
Nov & 2500 & 73 & 6 & 79 & $3,20 \%$ \\
Des & 2900 & 142 & 10 & 152 & $5,20 \%$ \\
Jan & 2600 & 81 & 12 & 93 & $3,60 \%$ \\
Feb & 2550 & 80 & 7 & 87 & $3,40 \%$ \\
Mar & 2150 & 107 & 9 & 116 & $5,40 \%$ \\
Apr & 2500 & 79 & 8 & 87 & $3,50 \%$ \\
Mei & 2100 & 86 & 9 & 95 & $4,50 \%$ \\
Juni & 2250 & 65 & 6 & 71 & $3,20 \%$ \\
\hline
\end{tabular}


Sumber : PT Tetra Mitra Sinergis

Tabel II. Data produk cacat baut type K21

\begin{tabular}{cccccc}
\hline \multicolumn{5}{c}{$\begin{array}{c}\text { LAPORAN PRODUKSI FINISING PART PRODUK } \\
\text { BAUT K21 }\end{array}$} & BULAN JULI 2018 - JUNI 2019 \\
\hline \multirow{3}{*}{ Bulan } & $\begin{array}{c}\text { Jumlah } \\
\text { produksi }\end{array}$ & $\begin{array}{c}\text { Jenis Cacat } \\
\text { Cacat }\end{array}$ & $\begin{array}{c}\text { Cacat } \\
\text { Warna }\end{array}$ & $\begin{array}{c}\text { Jumlah } \\
\text { Fisik }\end{array}$ & $\begin{array}{c}\text { Cacat } \\
\text { Persentase } \\
\text { Cacat }\end{array}$ \\
\hline Juli & 2550 & 120 & 8 & 128 & $5,00 \%$ \\
Agt & 2550 & 25 & 5 & 30 & $1,20 \%$ \\
Sept & 2550 & 28 & 10 & 38 & $1,50 \%$ \\
Okt & 2550 & 60 & 9 & 69 & $2,70 \%$ \\
Nov & 2550 & 73 & 6 & 79 & $3,10 \%$ \\
Des & 2550 & 70 & 10 & 80 & $3,10 \%$ \\
Jan & 2550 & 56 & 12 & 68 & $2,70 \%$ \\
Feb & 2550 & 56 & 7 & 63 & $2,50 \%$ \\
Mar & 2550 & 40 & 8 & 48 & $1,90 \%$ \\
Apr & 2550 & 70 & 5 & 75 & $2,90 \%$ \\
Mei & 2550 & 83 & 8 & 91 & $3,60 \%$ \\
Juni & 2550 & 65 & 10 & 75 & $2,90 \%$ \\
\hline
\end{tabular}

Sumber : PT Tetra Mitra Sinergis

Berdasarkan tabel I tersebut, dapat diketahui bahwa presentase cacat pada type baut K35 lebih memiliki jumlah cacat terbanyak di bandingkan baut type K21 dan sudah melewati batas presentase defect yang sudah ditetapkan oleh perusahaan sebesar 4\%, maka pada observasi tersebut harus adanya rancangan usulan perbaikan pada line manufaktur dengan menggunakan penerapan konsep lean manufacturing untuk mengurangi waste defect pada line proses nickel chrome baut type K35 dengan metode poka yoke, poka yoke adalah salah satu metode yang tepat dapat mencegah cacat yang diakibatkan oleh kesalahan manusia dalam bekerja (Dudek-Burlikowska \& Szewieczek, 2009).

\section{Metode Penelitian}

\section{A. Lean}

Lean dapat diidentifikasi sebagai suatu pendekatan sistemik dan sistematik untuk mengidentiifikasi dan menghilangkan pemborosan (waste), atau aktivitas yang tidak bernilai tambah (non-value-adding activities) melalui peningkatan terus-menerus (continues improvement) dengan cara mengalirkan produk (material, work-in-process, output) dan informasi mengggunakan sistem Tarik (pull system) dari internal dan eksternal untuk mengejar keunggulan dan kesempurnaan (Monden, 2011). Menurut (Kholil \& Pambudi, 2014), Menurut (Gaspersz, 2007) lean adalah suatu upaya terus menerus (continuous improvement effort) untuk menghilangkan pemborosan (waste), meningkatkan nilai tambah (value added) produk (barang dan/ jasa) dan memberikan nilai kepada pelanggan (customer value). 


\section{B. Metode Diagram Pareto}

Diagram Pareto merupakan salah satu tools (alat) dari QC 7 Tools yang sering digunakan dalam hal pengendalian Mutu. Pada dasarnya, Diagram pareto merupakan diagram yang terdiri dari atas grafik yang menggambarkan perbandingan masingmasing jenis data terhadap keseluruhan (Ginting, 2007) Kegunaan diagram pareto antara lain :

1. Menunjukkan persoalan-persoalan utama.

2. Menunjukkan perbandingan masing-masing persoalan.

3. Menunjukkan tingkat perbaikan setelah tindakan perbaikan.

4. Menunjukkan masing-masing persoalan sebelum dan sesudah perbaikan.

Metode Diagram Pareto digunakan pada penelitian ini untuk presentasi cacat prioritas.

\section{Metode Fishbone}

Diagram fishbone (diagram tulang ikan — karena bentuknya seperti tulang ikan) sering juga disebut Cause-and-Effect Diagram atau Ishikawa Diagram diperkenalkan oleh Dr. Kaoru Ishikawa, seorang ahli pengendalian kualitas dari Jepang, sebagai satu dari tujuh alat kualitas dasar (7 basic quality tools). Diagram fishbone digunakan ketika kita ingin mengidentifikasi kemungkinan penyebab masalah dan terutama ketika sebuah team cenderung jatuh berpikir pada rutinitas (Tague, 2005). Metode fishbone digunakan untuk mengetahui akar permasalahan.

D. Metode Poka Yoke

Poka Yoke berasal dari bahasa Jepang yang artinya adalah mencegah kesalahan yang dikarenakan oleh kecerobohan oleh tenaga kerja manusia. Menurut konsep Poka Yoke adalah suatu metode untuk meminimalisir error yang secara tidak disengaja dengan cara pemberian solusi yang sederhana (Syarifuddin \& Sofyan, 2018), pekerjalah yang sering disalahkan. Hal ini bukan saja dapat mematahkan semangat kerja karyawan tersebut tetapi juga tidak dapat menyelesaikan masalah yang terjadi. Oleh karena penerapan metode kerja poka yoke menjadi sangat penting dalam menghindari kesalahan yang terjadi. Metode poka yoke digunakan untuk memunculkan usulan perbaikan pada line nickel chrome.

\section{Hasil Penelitian dan Pembahasan}

Pada tahap ini akan digunakan diagram pareto yang berfungsi untuk mengetahui permasalahan. Tahap Diagram Pareto merupakan tahapan awal pada pengerjaan Poka Yoke. Diagram pareto salah satu tools (alat) dari QC 7 Tools yang sering digunakan dalam hal pengendalian Mutu. Pada dasarnya, Diagram Pareto adalah grafik batang yang menunjukkan masalah berdasarkan urutan banyaknya jumlah kejadian. Urutannya mulai dari jumlah permasalahan yang paling banyak terjadi sampai yang paling sedikit terjadi. Berikut adalah data pada produk cacat pada pembuatan baut type K35. Sehingga dapat mengetahui tingkat cacat pada proses pencelupan 
Bintang Nusantara Adji, Zeny Fatimah Hunusalela dan Anggi Oktaviani

Tabel III. Data Cacat Baut Type K35

\begin{tabular}{|c|c|c|c|c|c|}
\hline \multicolumn{6}{|c|}{$\begin{array}{l}\text { LAPORAN PRODUKSI FINISING PART PRODUK } \\
\text { BAUT TYPE K35 BULAN JULI } 2018 \text { - JUNI } 2019\end{array}$} \\
\hline \multirow[b]{2}{*}{ Bulan } & \multirow[b]{2}{*}{$\begin{array}{l}\text { Jumlah } \\
\text { produksi }\end{array}$} & \multicolumn{2}{|c|}{ Jenis Cacat } & \multirow[b]{2}{*}{$\begin{array}{l}\text { Jumlah } \\
\text { Cacat }\end{array}$} & \multirow[b]{2}{*}{$\begin{array}{l}\text { Persentase } \\
\text { Cacat }\end{array}$} \\
\hline & & $\begin{array}{l}\text { Cacat } \\
\text { Warna }\end{array}$ & $\begin{array}{l}\text { Cacat } \\
\text { Fisik }\end{array}$ & & \\
\hline Juli & 2550 & 112 & 8 & 120 & $4,70 \%$ \\
\hline Agt & 2000 & 42 & 7 & 49 & $2,50 \%$ \\
\hline Sept & 2300 & 70 & 10 & 80 & $3,50 \%$ \\
\hline Okt & 2600 & 118 & 9 & 127 & $4,90 \%$ \\
\hline Nov & 2500 & 73 & 6 & 79 & $3,20 \%$ \\
\hline Des & 2900 & 142 & 10 & 152 & $5,20 \%$ \\
\hline $\operatorname{Jan}$ & 2600 & 81 & 12 & 93 & $3,60 \%$ \\
\hline Feb & 2550 & 80 & 7 & 87 & $3,40 \%$ \\
\hline Mar & 2150 & 107 & 9 & 116 & $5,40 \%$ \\
\hline Apr & 2500 & 79 & 8 & 87 & $3,50 \%$ \\
\hline Mei & 2100 & 86 & 9 & 95 & $4,50 \%$ \\
\hline Juni & 2250 & 65 & 6 & 71 & $3,20 \%$ \\
\hline
\end{tabular}

Sumber : PT Tetra Mitra Sinergis

Berdasarkan data yang sudah diketahui, mengenai jumlah cacat yang terjadi selama bulan JULI 2018 - JUNI 2019. Data produk cacat tersebut dapat diolah untuk membuat diagram pareto guna untuk mengetahui cacat prioritas yang terjadi. Dilakukan tahapan diagram pareto prioritas type-type baut pada line nickel chrome berdasarkan data produksi cacat baut pada line nickel chrome.

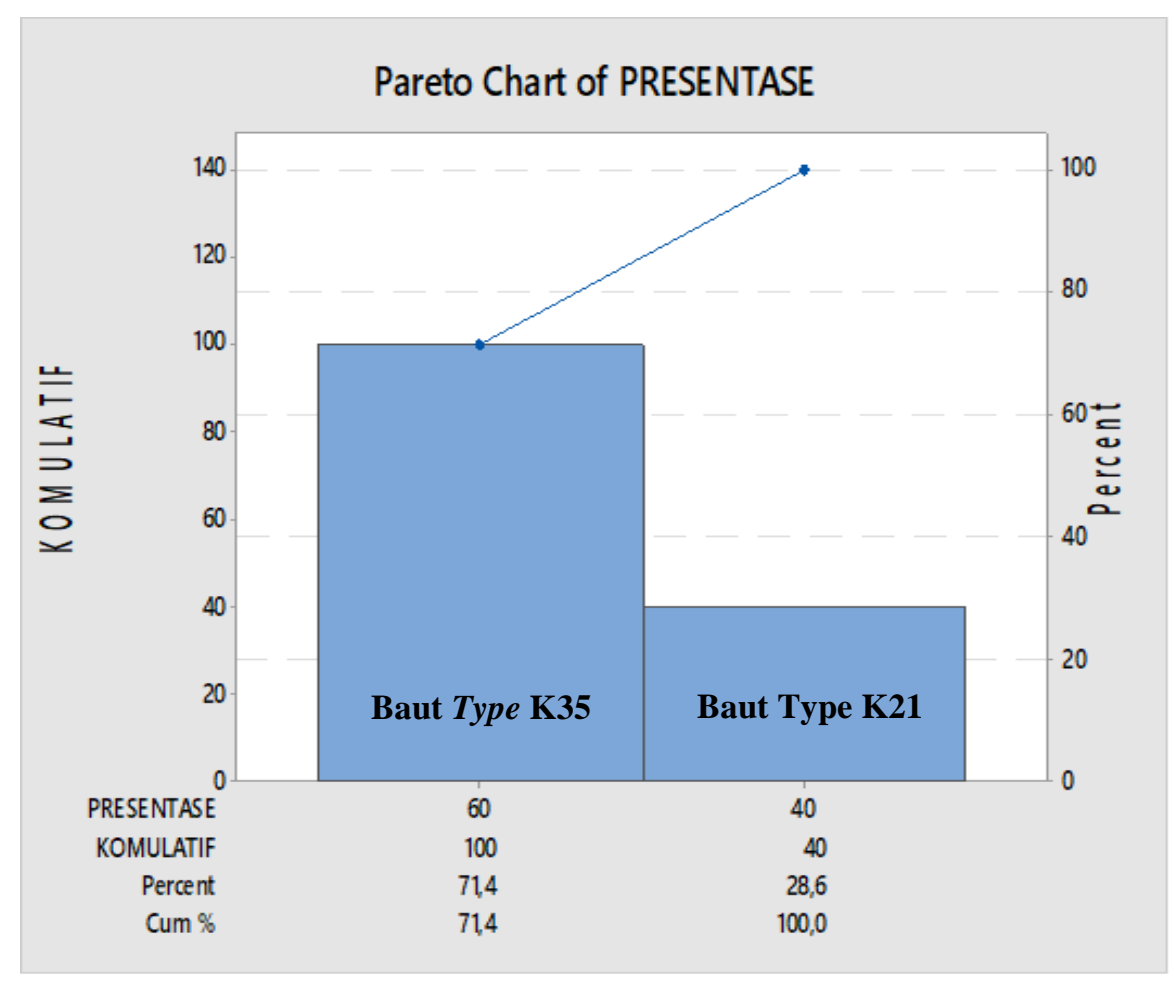

Gambar I. Diagram pareto presentase baut jenis K35 dan K21 periode Juli 2018 - Juni 2019 
Berdasarkan diagram pareto diatas dapat diketahui bahwa kelompok cacat terdapat pada Baut Type K35 adalah cacat yang menjadi prioritas atau cacat terbanyak. Untuk membuat diagram pareto seperti gambar diatas menggunakan MiniTab, harus mengetahui jumlah dari masing-masing reject dan dapat diketahui bahwa reject yang paling dominan adalah type baut K35, frekuensi cacat pada baut K21 844 dengan persentase sebesar 40\%, selanjutnya baut type K35 memiliki frekuensi sebesar 1281 dengan presentase $60 \%$. Berdasarkan pada prinsip pareto $20 \%$ masalah utama mewakili $80 \%$ masalah lainya, maka dari itu kecacatan yang melewati $20 \%$ yaitu baut jenis K35 masalah utama atau masalah yang menjadi prioritas untuk dianalisa.

Langkah selanjutnya dalam metode Poka Yoke adalah Observation at Workstation, yaitu memilih penyebab masalah produk cacat dengan menggunakan diagram tulang ikan atau (Fishbone Diagram). Alat fishbone diagram dapat menunjukkan penyebab-penyebab dari sebuah permasalah yang spesifik. Untuk membuat diagram fishbone ini data yang diambil dari masalah prioritas yang terdapat pada diagram pareto yang telah dilakukan perhitungan sebelum. Diagram sebab akibat ini perlu dilihat dari berbagai faktor, diantaranya dapat disebabkan oleh faktor manusia, mesin, metode, material dan faktor lingkungan. Pada faktor metode yang masalah akar permasalahannya adalah tidak ada SOP yang jelas, pada faktor mesin yang menjadi faktor permasalahannya adalah belum ada alat Poka Yoke, pada faktor lingkungan yang menjadi akar permasalahannya adalah Tata letak tidak efisien, pada faktor manusia yang menjadi akar permasalahannya adalah maintance kurang pelatihan, dan pada faktor material yang menjadi akar permasalahannya adalah barang tidak continue. Berikut ini adalah gambar dari diagram fishbone : 
Bintang Nusantara Adji, Zeny Fatimah Hunusalela dan Anggi Oktaviani

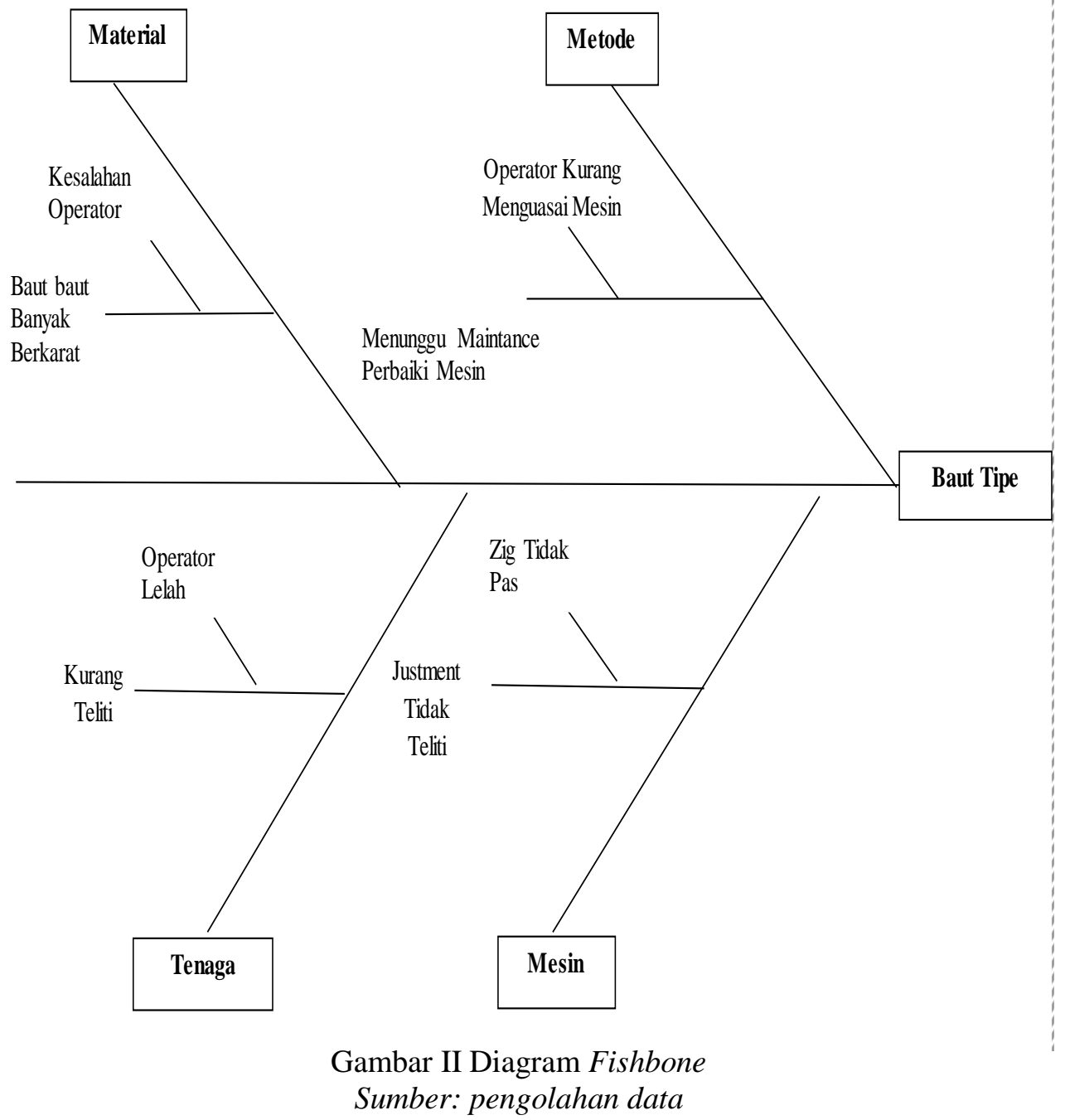

Dari hasil pengamatan diatas berdasarkan diagram fishbone dapat diketahui penyebab cacat pada baut berasal dari faktor mesin, material, metode dan lingkungan yang akan dijelaskan sebagai berikut:

a. Material, kesalahan pada operator yang mengakibatkan baut-baut banyak berkarat. Faktor itu dapat disebabkan karna kesalahan pada operator sehingga dapat membuat proses pencelupan pada acid larutan menjadi lama.

b. Metode, menunggu bagian pada pemeliharaan mesin mengalami masalah pada mesin pencelupan, masalah tersebut terjadi saat produksi berlangsung hal itu menjadi salah satu penyebab produk cacat dari factor metode. Menunggu maintenance memperbaiki mesinnya diakibatkan dari kurang nya pemahaman operator mesin dalam memperbaiki mesin.

c. Tenaga Kerja, kurang nya tingkat ketelitian pada pekerja dalam proses pencelupan baut pada acid larutan sehingga dapat menyebabkan produk cacat factor tersebut biasa termasuk kedalam factor tenaga kerja.

d. Mesin, kesalahan yang biasa nya timbul pada mesin diakibatkan oleh lalai nya operator yang mengakibatnya proses pencelupan pada baut K35 mengalami cacat, 
Penerapan Konsep Lean Manufacturing Untuk Rancangan Usulan Perbaikan Minimasi Waste Defect Dengan Metode Poka Yoke Pada PT. Tetra Mitra Sinergis

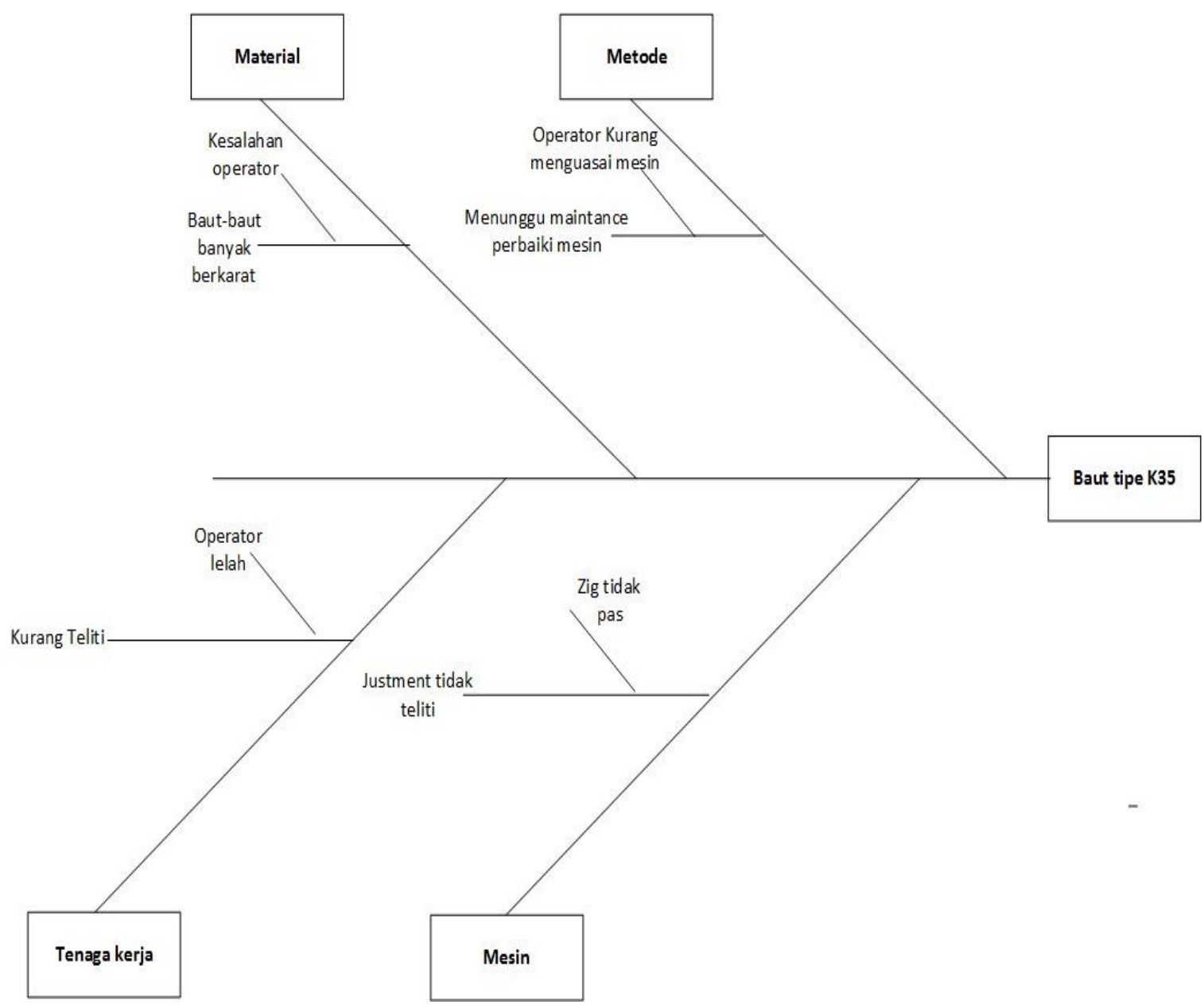

Gambar III Diagram Fishbone

Sumber: pengolahan data

Berdasarkan diagram tersebut dapat diketahui bahwa penyebab cacat pada proses pencelupan berasal dari factor material, metode, tenaga kerja dan mesin yang akan dijelaskan secara pokok sebagai berikut:

a. Material, operator tidak membaca SOP, sehingga kusam dan karat dikarenakan terlalu lama pada proses acid larutan, penyebab nya dikarenakan operator yang kurang hati-hati sehingga banyak baut yang mengalami cacat/defect, hal tersebut mempengaruhi kualitas pada produksi sehingga barang yang dihasilkan pada baut type K35 mengalami cacat yang tinggi. Lalai nya akan peraturan SOP juga membuat baut-baut yang berceceran.

b. Metode, Justment yang dilakukan oleh operator mesin masih dilakukan secara manual, hal tersebut menjadi penyebab yang biasa nya dapat menyebabkan cacat pada factor metode. Justment yang salah ini juga dapat terjadi akibat operator yang kurang nya hati-hati operator mesin dalam melakukan justment sehingga jika justment salah dilakukan yaitu terlalu lama didalam proses acid larutan maka berpotensi produk berkarat pada proses pencelupan. 
c. Tenaga kerja, insting operator mesin dalam melakukan justment salah merupakan penyebab cacat/defect yang biasa nya terjadi pada tenaga kerja. Kesalahan tersebut biasa nya dapat diakibatkan karena belum ada pelatihan, sehingga belum mengetahui perkiraan pencelupan baut ke dalam proses acid larutan yang akan mengakibatkan baut berkarat jika proses pencelupan baut terlalu lama. Proses tersebut yang biasanya mengalami cacat/defect karna proses pencelupan harus menggunakan insting yang kuat.

d. Mesin, kesalahan pada mesin yang mengakibatkan salah setingan pada proses pencelupan baut type K35 dapat membuat zig/barel tidak pas. Faktor penyebabpenyebab tersebut biasa nya dapat disebabkan oleh baut yang terlalu banyak di zig/barel membuat kapasitas mesin pada zig/barel terlalu banyak sehingga proses pencelupan tidak stabil mengakibatkan baut type K35 tercecer. Hal tersebut biasanya dikarenakan karna kurangnya hati-hati dalam proses pencelupan baut.

Brainstorming for idea merupakan suatu cara untuk mengatahui usulan perbaikan yang berasal dari idea-idea, usualan perbaikan guna untuk mengurangi cacat/defect pada proses pencelupan baut ke proses acid larutan, usulan perbaikan dari diagram tulang ikan, antara lain material, operator tidak membaca SOP, sehingga kusam dan karat dikarenakan terlalu lama pada proses acid larutan, penyebab nya dikarenakan operator yang kurang hati-hati sehingga banyak baut yang mengalami cacat/defect, hal tersebut mempengaruhi kualitas pada produksi sehingga barang yang dihasilkan pada baut type K35 mengalami cacat yang tinggi. Lalai nya akan peraturan SOP juga membuat baut-baut yang berjatuhan.

a. Metode, Justment yang dilakukan oleh operator mesin masih dilakukan secara manual, hal tersebut menjadi penyebab yang biasa nya dapat menyebabkan cacat pada factor metode. Justment yang salah ini juga dapat terjadi akibat operator yang kurang nya hati-hati operator mesin dalam melakukan justment sehingga jika justment salah dilakukan yaitu terlalu lama didalam proses acid larutan maka berpotensi produk berkarat pada proses pencelupan. Tenaga kerja, insting operator mesin dalam melakukan justment salah merupakan penyebab cacat/defect yang biasa nya terjadi pada tenaga kerja. Kesalahan tersebut biasa nya dapat diakibatkan karna belum ada pelatihan, sehingga belum mengetahui perkiraan pencelupan baut ke dalam proses acid larutan yang akan mengakibatkan baut berkarat jika proses pencelupan baut terlalu lama. Proses tersebut yang biasa nya mengalami cacat/defect karna proses pencelupan harus menggunakan insting yang kuat. Mesin, kesalahan pada mesin yang mengakibatkan salah setingan pada proses pencelupan baut type K35 dapat membuat zig/barel tidak pas. Factor penyebab-penyebab tersebut biasa nya dapat disebabkan oleh baut yang terlalu banyak di zig/barel membuat kapasitas mesin pada zig/barel terlalu banyak sehingga proses pencelupan tidak stabil mengakibatkan baut type K35 terjatuh. Hal tersebut biasa nya dikarenakan karna kurang nya hati-hati dalam proses pencelupan baut. 
b. Usulan perbaikan berdasarkan metode poka yoke, antara lain penggunaan alarm pada proses ke 5 yaitu bak acid larutan yang akan berbunyi pada saat terjadinya keterlambatan operator untuk mengangkat zig/barel untuk warning, penjadwalan alarm sesuai dengan waktu yang sudah ditentukan yaitu 5 menit. Operator line nickel chrome memperlambat laju produksi pada saat terjadinya kesalahan dan langsung melakukan pengecekan serta melakukan kontrol berupa perbaikan pada proses bak acid larutan saat alarm berbunyi dan operator akan menaikan zig yang tercelup di bak acid larutan.

Select Best Idea berupa pemilihan solusi dari beberapa solusi perbaikan yang terkumpul, pemilihan solusi terbaik adalah dengan menerapkan beberapa fungsi dari metode poka yoke, yaitu dimulai dari fungsi warning dan kontrol dikarenakan fungsi tersebut berkesinambungan dan merupakan satu rangkaian di dalam proses produksi, serta usulan perbaikan pada faktor manusia dari yang diambil dari diagram tulang ikan (fishbone) karena faktor manusia tersebut merupakan faktor dominan penyebab cacat. Adapun solusi terbaik tersebut adalah solusi perbaikan yang berdasarkan fungsi metode poka yoke dan faktor manusia dari diagram fishbone, menambah operator pada line nickel chrome yang bertugas mengoperasikan dan mendeteksi saat lamanya pada proses, sehingga jika sinyal atau alarm menyala operator yang mengoperasikan mesin dan pemberi instruksi titik letak kesalahan, sehingga jika sinyal atau alarm menyala operator mesin baru yang bertanggung jawab yang mengawasi jalannya produksi dan mengangkat zig/barel. Operator tambahan yang diusulkan dapat diambil dari bagian line produksi EDP yang menumpuk dikarenakan pada semua line produksi memakai mesin yang sama sehingga operator line produksi EDP mengenali pengoprasian mesin, sedangkan operator mesin yang mengawasi dan memperbaiki mesin sebaiknya merupakan operator lama pada proses line nickel chrome.

Pembahasan dan analisis dari hasil diagram fishbone faktor manusia merupakan faktor dominan penyebab cacat maka dari itu solusi terbaik menambah operator pada line nickel chrome yang bertugas mengoperasikan dan mendeteksi saat lamanya pada proses. Penambahan operator baru dapat diambil dari operator EDP. Hal ini menunjukan perlu diadakan nya penelitian lebih lanjut dan dilakukan suatu perubahan pada line produksi tersebut, hasil dari brainstorming menciptakan usulan dengan menambahkan warning yaitu berupa peringatan dimana operator akan mengetahui proses bak acid larutan adalah 5 menit, control berupa operator line nickel chrome memperlambat laju produksi pada saat terjadinya kesalahan dan langsung melakukan pengecekan serta melakukan kontrol berupa perbaikan pada proses bak acid larutan saat alarm berbunyi dan operator akan menaikan barel/zig yang tercelup di bak acid larutan dan pada proses terakhir bak tambahan guna menaruh hasil baut jadi operator tidak perlu untuk mengangkat zig/barel yang mengakibatkan jatuhnya baut, gambar usulan line produksi nickel chrome dapat dilihat pada gambar berikut. 
Bintang Nusantara Adji, Zeny Fatimah Hunusalela dan Anggi Oktaviani

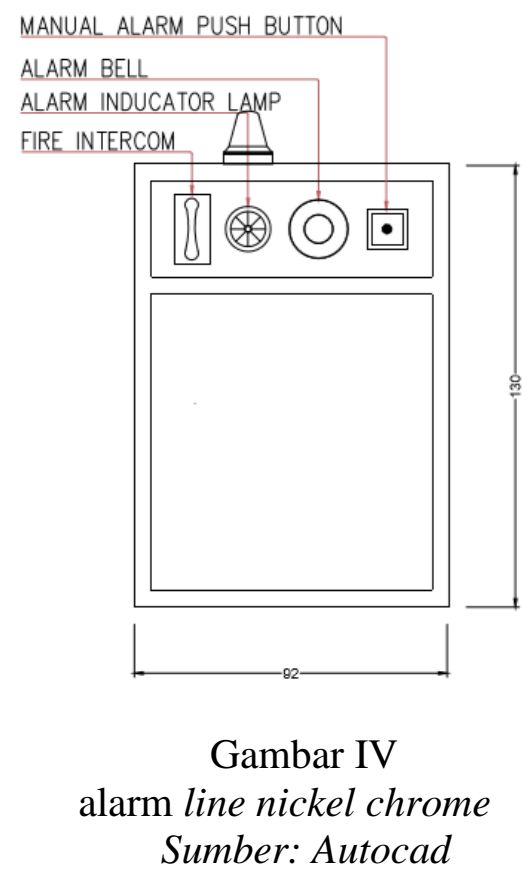

Perancangan Usulan alarm kerja pada line nickel chrome yang tercantum pada gambar IV didesain sesuai ukuran line produksi dan tidak menggangu operator atau jalannya produksi. Usulan perbaikan tersebut agar meminimasi cost pada waste defect.

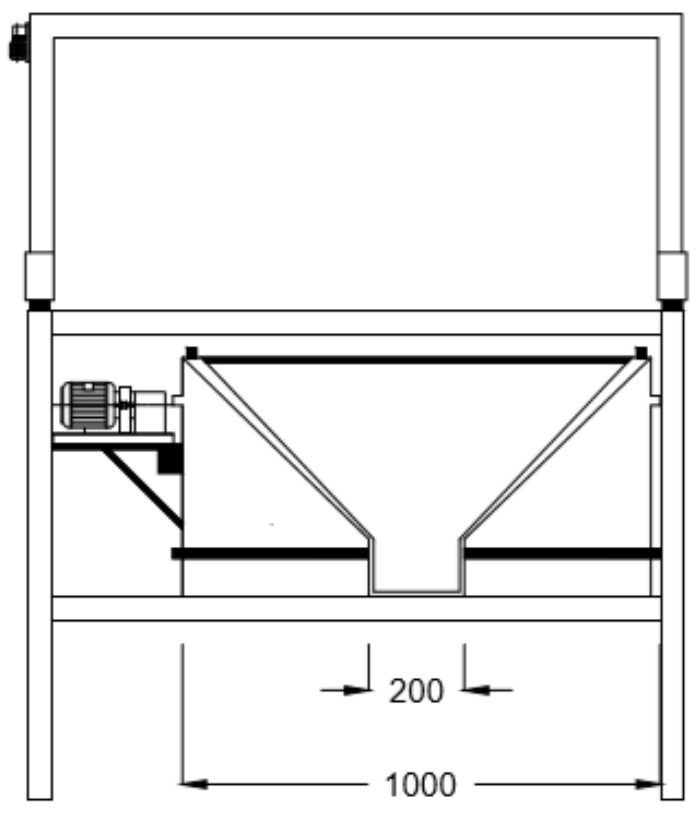

Bak Finishing

Sumber: Autocad

Pada gambar IV terlihat rancangan Line Produksi Nickel Chrome dari tampak atas pada proses pertama yaitu dinamakan proses acid larutan dimana baut yang sudah 
dimasukan didalam barel/zig lalu dimasukan didalam bak acid larutan berisi acid HCL dengan waktu 5 menit guna membuka pori-pori baut, tahap proses kedua yaitu dinamakan proses rinsing bak berisi air untuk mencuci baut yang sudah melewati tahap acid larutan guna mencuci baut dengan waktu 5 detik, pada tahap ketiga yaitu netralizer/degreasing untuk menetralisir baut dari noda dan kadar lainnya dengan waktu 10 menit, pada tahap keempat yaitu rinsing bak berisi air untuk mencuci baut yang sudah melewati tahap netralizer/degreasing dengan waktu 5 menit, pada tahap kelima yaitu chrome anoda yaitu bak berisi cairan zat aditip dengan butiran chrome anoda yang di gantungkan dengan tembaga bas bar dialiri tegangan listrik dari rectivayer dengan waktu 15-20 menit, pada tahap keenam yaitu rinsing bak berisi air untuk mencuci baut yang sudah melewati tahap chrome anoda dengan waktu 5 menit. Penambahan pada line produksi berupa bak untuk memudahkan operator untuk menaruh baut atau yang sudah selesai melewati proses keenam untuk bahan yang digunakan dalam pembuatan bak tambahan adalah baja dengan ketebalan $18 \mathrm{~mm}$ dengan tinggi $50 \mathrm{~cm}$ panjang $100 \mathrm{~cm}$ dan lebar $100 \mathrm{~cm}$ dapat dilihat pada gambar V. Ukuran dimensi bak tambahan pada line nickel chrome yang digunakan saat ini didapatkan dengan melakukan pengukuran secara langsung.

\section{Kesimpulan}

Berdasarkan hasil penelitian yang telah dilakukan mengenai pemecahan masalah mengenai line manufaktur yang di sebabkan oleh manusia maka dapat ditemukan kesimpulan:

1. Cacat presentase cacat baut nickel chroum K35 dan K21 pada PT. Tetra Mitra Sinergis, frekuensi cacat pada baut K21 844 dengan persentase sebesar 40\%, selanjutnya baut type K35 memiliki frekuensi sebesar 1281 dengan persentase $60 \%$.

2. Proses produksi pada line nickel chrome yaitu, pada proses pertama yaitu dinamakan proses acid larutan dimana baut yang sudah dimasukan didalam zig/barel lalu dimasukan didalam bak acid larutan berisi acid HCL dengan waktu 5 menit guna membuka pori-pori baut, tahap proses kedua yaitu dinamakan proses rinsing bak berisi air untuk mencuci baut yang sudah melewati tahap acid larutan guna mencuci baut dengan waktu 5 detik, pada tahap ketiga yaitu netralizer/degreasing untuk menetralisir baut dari noda dan kadar lainnya dengan waktu 10 menit, pada tahap keempat yaitu rinsing bak berisi air untuk mencuci baut yang sudah melewati tahap netralizer/degreasing dengan waktu 5 menit, pada tahap kelima yaitu chrome anoda yaitu bak berisi cairan zat aditip dengan butiran chrome anoda yang di gantungkan dengan tembaga bas bar dialiri tegangan listrik dari rectivayer dengan waktu 15-20 menit, pada tahap keenam yaitu rinsing bak berisi air untuk mencuci baut yang sudah melewati tahap chrome anoda dengan waktu 5 menit

3. Usulan perbaikan yang dapat diberikan dengan menggunakan metode poka yoke adalah dengan menggunakan beberapa fungsi poka yoke yaitu pemberian alarm pada saat terjadi kesalah berupa lamanya pencelupan pada bak acid larutan dan control yang berupa operator yang dengan manual akan menaikan zig/barel dengan manual. 
Bintang Nusantara Adji, Zeny Fatimah Hunusalela dan Anggi Oktaviani

Selain itu dengan menambahkan operator pada line nickel chrome untuk mengoperasikan mesin dan berjaga-jaga jika ada kesalahan pada line nickel chrome 
Penerapan Konsep Lean Manufacturing Untuk Rancangan Usulan Perbaikan Minimasi

Waste Defect Dengan Metode Poka Yoke Pada PT. Tetra Mitra Sinergis

\section{Bibliografi}

Dudek-Burlikowska, Marta, \& Szewieczek, D. (2009). The Poka-Yoke method as an improving quality tool of operations in the process. Journal of Achievements in Materials and Manufacturing Engineering, 36(1), 95-102.

Dwiningrum, Siti Irene Astuti, \& Purbani, Widyastuti. (2012). Manusia berkarakter dalam perspektif guru dan siswa. Jurnal Kependidikan: Penelitian Inovasi Pembelajaran, 42(1).

Gaspersz, Vincent. (2007). Lean Six Sigma. Gramedia Pustaka Utama.

Ginting, Rosnani. (2007). Sistem produksi.

Hines, Peter, \& Taylor, David. (2000). Going Lean, Lean Enterprise Research Center. Cardiff Bussiness School.

Kholil, Muhammad, \& Pambudi, Tri. (2014). Implementasi Lean Six Sigma Dalam Peningkatan Kualitas Dengan Mengurangi Produk Cacat Ng Drop Di Mesin Final Test Produk Hl 4.8 Di PT. Ssi. Penelitian Dan Aplikasi Sistem Dan Teknik Industri, 8(1), 182844.

Monden, Yasuhiro. (2011). Toyota production system: an integrated approach to justin-time. CRc Press.

Syarifuddin, Syarifuddin, \& Sofyan, Diana Khairani. (2018). Analisis Biaya Kehilangan (LOSS COST) DARI Produk Air Minum dalam Kemasan (AMDK) Menggunakan Metode Poka Yoke. Jurnal Optimalisasi, 2(3).

Tague, Nancy R. (2005). The Quality Toolbox, American Society for Quality. Quality Press, Milwaukee.

Wahyuningtias, Kiki Adelina. (2013). Pengaruh Biaya Kualitas Terhadap Produk Rusak Pada CV. Ake Abadi. Jurnal EMBA: Jurnal Riset Ekonomi, Manajemen, Bisnis Dan Akuntansi, 1(3).

Wahyuningtias, Kiki Adelina. "Pengaruh Biaya Kualitas Terhadap Produk Rusak Pada CV. Ake Abadi." Jurnal EMBA: Jurnal Riset Ekonomi, Manajemen, Bisnis dan Akuntansi 1.3 (2013). 